Grand Valley State University

ScholarWorks@GVSU

Winter 1990

\title{
Vom Nutzen und Nachteil der Literatur für die Geschichtswissenschaft: A Historian's View
}

Gary D. Stark

Grand Valley State University, starkg@gvsu.edu

Follow this and additional works at: https://scholarworks.gvsu.edu/hst_articles

Part of the History Commons

\section{ScholarWorks Citation}

Stark, Gary D., "Vom Nutzen und Nachteil der Literatur für die Geschichtswissenschaft: A Historian's View" (1990). Peer Reviewed Articles. 7.

https://scholarworks.gvsu.edu/hst_articles/7

This Article is brought to you for free and open access by the History Department at ScholarWorks@GVSU. It has been accepted for inclusion in Peer Reviewed Articles by an authorized administrator of ScholarWorks@GVSU. For more information, please contact scholarworks@gvsu.edu. 
GARY D. STARK

University of Texas, Arlington

\section{Vom Nutzen und Nachteil der Literatur für die Geschichtswissenschaft: A Historian's View}

Ever since Aristotle observed that historians tell about what has happened while poets tell about what might happen, ${ }^{1}$ the relationship between art and reality has been a controversial one. It is hardly my intention here to settle definitively this perennial question or to judge whether history or literature, memory or imagination is more truthful or provides a superior form of knowledge. Rather, as a historian I wish to explore the value and limitations of imaginative literature as a source of reliable information about life in the past and to comment on some of the ways historians can use and abuse literature as historical evidence.

\section{I}

Literature is commonly assumed to be a valuable source of information about life in the past. Historians and others have a long tradition of treating literary works as repositories of useful historical evidence, as important windows onto the events, developments, and conditions of earlier times. Herder, for example, believed that by studying a nation's literature,

lernen wir Zeiten und Nationen gewiß tiefer kennen als auf dem täuschenden trostlosen Wege ihrer politischen und Kriegsgeschichte. In dieser sehen wir selten mehr von einem Volke, als wie sie regieren und tödten ließ; in jener lernen wir, wie es dachte, was es wünschte und wollte, wie es sich erfreute, und von seinen Lehrern oder seinen Neigungen geführt ward. ${ }^{2}$

Herder's contemporary, Louis de Bonald, was equally confident that, "Were one to see the literature of a people whose history one does not know, one could tell what this people had been."' A more recent example from the field of German studies is Paret's new Art as History, which uses paintings, graphics, novels, and poems as historical sources for exploring nineteenth-century German politics and culture. Literary texts and visual images, Paret declares, are "rich deposits of historical evidence" that "reflect" and "document" facets of the times in which they originated. Artistic creations, he argues, especially those that treat contemporary incidents or conditions, can be valuable sources for the historical understanding of later generations because they "are among society's most determined efforts to understand itself, and through their insights, errors, and obfuscations we hear the clear voice of the past." 4

Intellectual historians have traditionally been the ones who have valued most highly - and used most extensively - literature as historical evidence. Because of their interest in the history of ideas and of intellectual activity and because fictional literature is one of the primary vehicles through which certain ideas are expressed and transmitted, intellectual historians have always seen creative writers as both influential shapers and sensitive registrars of the larger intellectual currents and general mental climate of their times. Intellectual history focuses on the intellectual content of literary works, for it tends to see literature as a kind of intellectual statement couched in a special artistic form. A work of imaginative literature is often treated as a vehicle for its author's ideas and is used as a document that reflects the intellectual currents of the past. Traditional intellectual history thus analyzes the ideas authors expressed through their 
literary creations; it relates these ideas to the author's personality or social and intellectual experiences, studies the relationship between the ideas found in literature and those being expressed by other thinkers of the age, and analyzes to what extent an imaginative writer's ideas were influenced by and in turn influenced the broader economic, social, political, and intellectual conditions of the times. In short, intellectual historians have traditionally used literary works as more or less transparent windows into the mental processes of past writers and, by extension, into the broader intellectual currents and general intellectual climate that shaped those processes.

Such a use of literature for historical purposes has always involved some methodological problems. First, as most literary scholars would quickly point out, it is a mistake to view a complex literary artwork as though it were a straightforward, systematic statement of ideas, similar to a philosophical essay, a political treatise, or other types of discursive prose. A work of poetic fiction serves quite different purposes, employs different methods, and has different results than do formal works of disquisition; to read a poem, novel, or drama as one might read a work of expository prose is to misread it, for it would be mistaking one genre of writing for another. ${ }^{5}$ Second, because the fictional world created by a poem, novel, or drama is a verbal world, "determined at every point by the words in which it is represented,"6 one cannot separate "form" from "content," what a work says from how it does so. In other words, fictions are nonparaphrasable: a change in the wording results in a change in the meaning. ${ }^{7}$ Third, "ideas" or propositions expressed in a literary work having meaning and significance only in relation to the total context of the work; to abstract them from the larger structure of the whole and examine them in isolation is necessarily to misconstrue them. Complex works of literature - much less isolated passages or phrases extracted from them-cannot be summarized or reduced to simple doctrinal statements without committing a reductive error (the so-called "heresy of paraphrase") that distorts them by removing them from their proper context. Intellectual historians who look only to the intellectual content of a work of literature without considering its modifying artistic form or without realizing that the aims and techniques of an imaginative writer are quite different from those of a philosopher or a social theorist are likely to be led seriously astray.

Another mistake frequently committed by historians who use literature to study the history of ideas is to confuse the point of view. One must not assume that an idea, attitude, or point of view expressed by a novel's narrator or by a particular character in a fictional work reflects the author's point of view. In literary texts one finds multiple "voices" or displacements of the author into narrator, persona, character; to determine which (if any) of the many voices in a work is speaking for the author, additional research is usually necessary in nonliterary sources, such as the author's letters or diaries. ${ }^{8}$ For this reason, biographers or intellectual historians cannot (or rather, should not) deduce much about an author's life or opinions from the author's fictional creations. The relation between an author's private life and his/her creative work is not a simple cause-and-effect relation, and a work of art is not a simple document for biography:

The whole view that art is self-expression pure and simple, the transcript of personal feelings and experiences, is demonstrably false. Even when there is a close relationship between the work of art and the life of an author, this must never be construed as meaning that the work of art is a mere copy of life. The biographical approach forgets that a work of art is not simply the embodiment of experience but always the latest work in a series of such works; it is a drama, a novel, a poem determined, so far as it is determined at all, by literary tradition and convention. $^{9}$

Or as the German intellectual historian Peter Paret concludes in his latest study, "the richer [a work's] aesthetic substance, the less likely that historical inquiry will penetrate to its core. . . . Works of art, more than other kinds 
of evidence, demand our recognition that in the end those qualities that make up their essential nature lie beyond the historian's reach." ${ }^{10}$

Such problems pale in comparison to those presented to intellectual historians by the last several decades of literary theory. By calling into question traditional assumptions about the relation between a literary text and its author, movements like formalism, linguistics, new criticism, structuralism, poststructuralism, hermeneutics, semiotics, and deconstruction have all but pulled the conceptual rug out from under traditional intellectual historians who have relied on literature as a simple window into the past. These new schools of interpretation, reacting against the historical, contextual, and other extrinsic approaches to literature, have shifted attention away from the author and his/her historical setting to the internal aesthetic structure and form of the literary artwork itself. Increasingly literary scholarship has lost interest in what literature says and has focused instead on the way it says it-i.e., on how literary discourse works.

Approximately since the First World War, the literary text has come to be seen as a virtually autonomous thing-in-itself, a "verbal icon" goverened by its own intrinsic artistic principles, structures, and strategies. Much of literary theory now treats literature as a self-contained, self-generating system of recurring, transhistorical forms, verbal structures, linguistic conventions, codes, and signs that arise out of the very nature of language. These deeper language codes and structures that lie behind the literary text are closed and autonomous in that they are sealed off from external influences such as the intentions of human subjects, or various intellectual traditions, or historical settings; they are selfreferring in that they form an unintended and arbitrary system of signs that refers only to itself. The literary artifact has been severed from its author and insulated from its historical setting. A work of literature, like any structure of language, can no longer be seen as a public expression of a past author's private mental reflections (indeed, the very concept of an "author" has been challenged as an ideological construct, and Barthes has even declared all authors dead ${ }^{11}$ ). Rather than being an act of self-expression by a human subject, literary texts are increasingly treated as products of a transhistorical linguistic or symbolic system, a creation of language itself. Modern literary theory has thus dehistoricized literature by shifting attention away from the external circumstances and historical setting of a literary work to its intrinsic aesthetic or linguistic elements; from the (historical) context to the text itself; from the time-bound contents of literary works to their timeless forms and structures; and from the expressive subjects or "authorial minds" of the past to the deeper, larger language or discourse that speaks through them.

The ahistorical or even anti-historical thrust of much twentieth-century literary scholarship thus poses a serious problem for intellectual historians who have traditionally considered literature as an intellectual document that can be used to reconstruct the past and recover the intentions of bygone authors. Indeed, in the $1980 \mathrm{~s}$, as intellectual historians have come to realize the implications of structuralism, deconstruction, semiotics, language theory, and the like, many in the field have recognized a crisis in their discipline and have begun fundamentally rethinking the premises, goals, and methods of intellectual history, especially the way in which it reads and uses literary texts. ${ }^{12}$ Increasingly intellectual historians realize that language can no longer be regarded as a transparent medium of expression; that texts, literary or otherwise, are not "merely congealed intentionalities waiting to be re-expressed at a later date"; and that interpreting a cultural product like a novel does not mean recovering the intentionality of its original author. ${ }^{13}$ When using literary texts, intellectual historians would do well to heed the warning of Rodway, who has pointed out that "no literary work can constitute valid evidence in any more general field until its own [intrinsic] nature has been rightly assessed." ${ }^{14}$ Before exploring the highly prob- 
lematic relation between a text and its various contexts (e.g., the author's life, the author's "intention," the "society," other modes of discourse) intellectual historians must first learn to see literary texts not as "documents" but as "works" or "texts": they must learn to deemphasize the author's supposed intent and pay more attention to such textual features as the work's linguistic dimensions, its narrative structure, and its rhetorical strategies in short, how it functions as discourse. ${ }^{15}$ Literature, we now realize, is hardly a transparent window onto the thinkers and ideas of the past; intellectual historians who hope to use literary texts as historical evidence will have to learn to use them in quite different ways.

\section{II}

If literary scholarship has seemed to move away from history in our century, much of historical scholarship has also moved away from literature. In the same decades that formalism, new criticism, structuralism, and poststructuralism came to the forefront of literary scholarship, traditional forms of historical scholarship such as intellectual history were being seriously challenged and largely displaced by social history. Before the rise of social history, most historians did history "from the top," focusing their attention on the actions and lives of powerful and influential elites, whether rulers or intellectuals. Recent social history, by contrast, has attempted to do "history from below," focusing attention on the lives of everyday, anonymous, ordinary people - the submerged mass of humanity who not only did not create literary texts but usually did not read them either, often because of illiteracy.

Considered as documents that record the perceptions, opinions, and experiences of a small cultural elite, literary works are of little use to the social historian. Social historians are interested not in what a few creative people thought but in how most people actually lived - and in most historical situations, the lives of everyday people are largely untouched by the intellectual currents that come to ex- pression in imaginative literature. Literature is of use to the social historian only if it provides factual information or useful knowledge ("evidence") about the past social life of ordinary people. Such information is conceivably present in the works of past authors who dealt with contemporary social problems and who included much detailed social observation and commentary about the lives of their characters and the social milieu in which those fictional characters operated. Works such as those of the nineteenth-century French realists or the German naturalists - who wanted art to be true to life, who wrote in a deliberately socially realistic style, and who included a wealth of detailed, realistic observations and descriptions about the social conditions of their times - might thus be a valuable source of information for twentieth-century social historians. No less a social observer than Engels, for example, remarked that Balzac "gives us a most wonderfully realistic history of French 'Society' . . . from which I have learned more than from all the professed historians, economists, and statisticians of the period together," while two prominent twentieth-century literary theorists state: "It is the great novelists above all who give us our social history: compared with what is done in their work - their creative work - the histories of the professional historians seem empty and unenlightening." 16

Unfortunately, social historians who look to the contents of literature as a source of information and evidence about past social conditions also face a number of problems and pitfalls. No matter how socially realistic or mimetic a literary work purports to be, no matter how full of detailed social observation and description, it does not provide historians with a simple mirror of past social reality. ${ }^{17}$

First, it would be a fallacy to assume that just because a writer intended to portray social conditions realistically, he/she in fact did so. Intention is not the same as achievement; we cannot assume that authors who strove for social realism actually succeeded in attaining it, or that authors who claim to depict historically accurate social conditions in their 
works actually do so. To avoid the "intentional fallacy," therefore, we must not treat a realistic or naturalistic novel as reliable social history merely because its author sought to write as a social historian. ${ }^{18}$

Second, literary works present only indirect, not direct, evidence about the events or conditions they portray and are thus for historians seldom the best relevant evidence. Conscientious historians are bound by what has been called the "rule of immediacy": they must provide not only evidence for their conclusions but the best relevant evidence - that is, "evidence which is most nearly immediate to the event itself." ${ }^{19}$ On this scale, after the event itself, the next best evidence would be authentic documents or other remains of the event, then direct observations, and so on. Even if an imaginative writer had directly observed the events or conditions he/she writes about - which is seldom the case - any literary account of past events is an indirect, ex post facto, highly mediated account that, by its very nature, mixes its social observation with imagination and reflection. As historical evidence, therefore, literary works rank quite low on the scale of immediacy, and thus they are seldom the best relevant evidence about the past. Even when one can determine, from external evidence, how close particular authors actually were to the events they describe and how they obtained their information about the social conditions they portray, the historically useful insights their literary works can offer are likely to be minimal in comparison with what we know from other, more direct, nonliterary sources.

Third, while socially realistic literary works may contain a wealth of social details (as do many of the novels and dramas of the German naturalists, for example), we cannot assume that these details are in fact accurate depictions of historical conditions. The only way we can be sure of their historical accuracy is to corroborate them by using external, nonliterary evidence. Social details in a fictive work are not necessarily social facts, and specificity by a writer is not necessarily accuracy. It is ironic but true, as Laslett reminds us, that fictional works are generally most reliable concerning precisely those things that are most incidental or peripheral to the main plot or to the author's central concerns: we are more likely to encounter historically accurate (and independently confirmable) information from an author's detailed descriptions of everyday physical objects or the material environment than from his/her treatment of socially interesting-but more complex and abstract - "facts," such as social stratification, class relationships, or the nature of family life. The great danger lies in inferring that because an author accurately depicts certain incidental elements of the physical environment of the past, he/she also gives an accurate account of the larger social events, situations, or relationships with which those physical descriptions are associated in the work. ${ }^{20}$

Fourth, historians who comb literary works for useful historical details too often forget that in a literary text, details are used for aesthetic purposes; they exist within a larger, intricate artistic whole and cannot-or rather, should not - be extracted from their aesthetic context. ${ }^{21}$ However realistic their literary style, imaginative writers have chosen to write a work of literature, not of history, and therefore we must presume that artistic, not historical truth is their primary concern. Writers include, leave out, emphasize, or deemphasize various details, not for their own sake but for larger aesthetic purposes; because imaginative writers use imagination, they "will exaggerate, colour up and tone down, for aesthetic effect, for subjective, psychological reasons, and must end by suppressing some things and inventing others."22 On the one hand, this problem of "literary license" means a researcher will never know, from the text itself, just what social details an author has chosen to leave out of the story. And it also means, on the other hand, that the social details included in a work of fiction have meaning only because they are part of a larger aesthetic structure or context. They should not be extracted arbitrarily from this context and squeezed into a completely different context. Before judging the value, mean- 
ing, or significance of any individual detail or "fact" in a literary work, the historian must first understand the work as an aesthetic whole and understand what role the "fact" plays within it. Again, as both historians and literary critics frequently remind us, fictive writing must be judged artistically as well as (or rather than) historically, for art is not the same as history or sociology. ${ }^{23}$ "The novelist is only metaphorically and incidentally a historian; whatever the relations of his art with the 'realities' of society, he is finally involved in the making of fictions, and has responsibilities to form that the historian or sociologist does not." 24

Finally, those social historians fortunate enough to find accurate, historically reliable details of social observation in literary works must beware of two additional fallacies: the fallacy of the lonely fact, and the fallacy of composition. That is, they must beware of generalizing from a single case, and of reasoning from a member of a group to the group itself. ${ }^{25}$ Responsible social historians must always ask just how representative are the particular social "facts" found in literary works. Characters or situations depicted in literature are often composites, "ideal types," which may well lack a "temporally specific context" -i.e., there may never have been a person, a group, a time, or a place that actually possessed all (or even most) of the attributes portrayed by the author. ${ }^{26}$ Even when the situations or attributes depicted in the work do correspond to a temporally specific context, such details may not have been common or typical in the past. When fiction portrays certain kinds of social behavior or situations, the historian must ask how widespread or frequent such behavior or situations actually were. This, of course, is something that again can be determined only by using other, nonliterary sources. Bramsted, who attempted to use the realistic German novels of the nineteenth century to study the social lives and relations of the German aristocracy and middle classes, cautioned that:

Only a person who has a knowledge of the structure of a society from other sources than purely literary ones is able to find out if, and how far, certain social types and their behavior are reproduced in the novel in an adequate or inadequate manner. What is pure fancy, what realistic observation, and what only an expression of the desires of the author must be separated in each case in a subtle manner. ${ }^{27}$

Indeed, the fact of the matter is that even the author probably did not-and could notknow just how socially typical or frequent any given attribute, situation, or event really was. For to make inferences about typicality or untypicality requires a systematic, quantitative knowledge about the entire population, a knowledge that few, if any, contemporaries ever possess. ${ }^{28}$

In short, historians must always be aware of what one scholar has called the "reversibility" of literary evidence, i.e., the fact that a literary work "can represent either the perfectly ordinary or the quite extraordinary," and we are never quite sure just which way a work should be read. ${ }^{29}$ We would do well to recall here Huxley's remark about "the chief difference between literature and life. In books, the proportion of exceptional to commonplace people is high; in reality, very low." ${ }^{30}$ It is easy to generalize about the past on the basis of a small sample or one lonely fact, but this is poor history.

In summary, using literature to do social history is a highly problematic undertaking. As Laslett has pointed out, using literary evidence is a "theory-laden activity." Before social historians can use literature, they must have a set of interconnected theoretical criteria for deciding such issues as: What is central and what is incidental to the literary theme? What was the artist's purpose in creating the particular work? How is that purpose related to the interests, attitudes, expectations, and outlook of the society or group to which the author and his/her expected readers belonged? To what extent might the work contain elements of the unconscious or fantasy life of the writer? How is fantasy related to real life, now and in the past? In what way can the work be said to be determined by the 
social setting and personality of the writer? "And finally he has to have a theory of the relationships between 'truths' of disparate kinds, poetic truths and historic truths especially." 31

Even when attacked with the appropriate theoretical weapons, however, imaginative literature provides us only with impressionistic - and sometimes even systematically deceptive-information about past social reality and thus proves an unreliable historical document. Despite their artistic talent, imaginative writers are in no better position to provide us with accurate observations about social reality than are other social observers, such as journalists or government officials. Indeed, they are arguably in a worse position precisely because they have chosen to write in a fictional mode that mingles imagination with social observation and strives for artistic rather than historical truth. Consequently, as one social historian has remarked,

nearly everything drawn from literature must be verified. In light of the deliberatively fictional nature of the novel, unusual information found there must be compared with data from other sources. But this procedure of verification ironically eliminates the need for the novel's evidence except, perhaps, for anecdotal [or illustrative] material. ${ }^{32}$

Unless the information found in literature can be checked against other sources, it remains impressionistic and merely suggestive; but when literature merely confirms what one knows from other documentary sources, literary evidence becomes redundant and superfluous. ${ }^{33}$ Clearly literature does not provide the social historian with a simple mirror of the actual conditions of the past. What is reflected in the social content of literary works is not the writer's society but at best the writer ${ }^{34}$ - and as we have seen, even that assumption has become highly questionable. For these reasons, social history that relies heavily on literary evidence for knowledge about past social realities is not very reliable as history.
III

So far I have given a rather pessimistic view of what historians might learn from literature. It is certainly difficult (in light of recent literary theory, some would insist even impossible) to go from text back to context, to use the contents of literary texts to reconstruct historical contexts, either intellectual or social. Can literature be used to understand anything other than literature?

Using examples from the field of interdisciplinary German Studies, I would like to offer a few modest suggestions on how historians might still look to literature to expand their knowledge about the past without falling too deeply into the theoretical and methodological pitfalls discussed above. Although we can no longer consider it the simple, transparent window onto past minds or the faithful mirror of past social conditions that we once did, I still maintain that both intellectual and social historians can use literature to expand our empirical knowledge of the past.

First, a broader view of "literature" can yield - and has yielded - a deeper understanding of the workings and historical evolution of the larger German social, economic, and political system of which literature was a part. We need to look less to individual literary texts and more to literature as a social process -i.e., to see literature or literary life as one of many social and economic institutions in Germany. Imaginative writers have always constituted a relatively distinct, although comparatively small, social elite; writers in Germany can be, and have been, studied empirically in much the same way as other elites - such as the aristocracy - or other social groups - such as artisans, factory workers, or civil servants. ${ }^{35}$ Writers, however, form only a part of the entire literary process. As the recent reader-response or Rezeptionsästhetik movement in literary theory has made clear, readers of imaginative literature are at least as important as writers in the literary process. Moreover, one must not forget all the intermediaries between author and reader, like book publishers, book sellers, and 
book reviewers. One must view literature as an entire process of production, distribution, and consumption involving many essentially distinct yet interacting social and economic groups. When seen as a social process or as a socioeconomic institution, imaginative literature constitutes an undeniably important segment within German social and economic life. Indeed, one could make a compelling argument that literary activity, broadly defined, has played a relatively larger role within the German social and economic system than it has in many other nations (by involving, for example, a greater percentage of the population). Clearly our knowledge of the changing historical structure of German society and of the German economy will remain incomplete without a firm understanding of the changing historical role that all these producers, purveyors, and consumers of imaginative literature have played within these larger systems. What is needed is a historical sociology of literature in Germany, a social history of reading, writing, and publishing. One could ask such questions as: How has the size, social composition, economic basis, and social prestige of Germany's literary class changed over time, and why? What social, political, and economic roles and functions have literary products, and their creators, distributors, and consumers played in German society? How have those individuals or groups involved in the literary process related to other German social groups and economic institutions? How have various social or economic or political institutions in Germany functioned to facilitate - or to hinder - the literary process?

Taking only this last question, it is evident that German literary publishers serve as important intermediaries between authors and readers. A number of recent studies of German publishers' relations with their authors have revealed just how influential such entrepreneurs have been in the creation and popular success of much nineteenth- and twentiethcentury fiction. ${ }^{36}$ While publishers promote the literary process, censors inhibit it. Studies of literary censorship in Germany can reveal a good deal about how censorship affected imaginative writers and what they wrote, and how censorship influenced the dissemination and public reception of literary works. ${ }^{37}$

The sociological study of German literary life and literary institutions can also add to our understanding of German political culture. Various social institutions and political movements in German history recognized the importance of imaginative literature and frequently sought to use the creation, distribution, or consumption of literary creations for their own purposes. One recent study, for example, has examined the way in which both elite and popular literature was discussed and disseminated in the feuilleton literary sections of nineteenth-century German newspapers. Fiction in the daily press, this study concludes, functioned as an agent of political socialization and ultimately served to justify and perpetuate the existing social and political order. ${ }^{38} \mathrm{By}$ contrast, an analysis of the complex role that poetry, drama, and fiction played within the subculture created by the socialist labor movement in late nineteenth-century Germany has demonstrated how "socialists and trade unionists made intensive use of various forms of literature, poetry, and drama especially, to broadcast their criticism of contemporary German society and to promote their views of an alternative." 39 Depending on the context, then, popular literature has been used both to uphold and to undermine the sociopolitical status quo in Germany. Clearly the various, often contradictory ideological functions and political uses that literature and literary life can have in various historical settings is an area that deserves far more research.

Second, the study of certain kinds of literary texts, especially widely disseminated popular fiction, can reveal much about the popular mentality of Germans in the past. With the rise of social history and its emphasis on the daily lives of the broad masses, interest in traditional intellectual history and the history of ideas-i.e., in the conscious thoughts, values, and creative activities of a narrow cultural elite - has been overshadowed by a new interest in the implicit, often unconscious be- 
lief structures and mental systems of the wider populace. Inspired partly by late nineteenth-century notions of a "collective psyche" but far more by the structuralist approach of the French Annales school, modern social and intellectual historians have focused on "mentalité," defined as that "ensemble of aspirations, sentiments, and ideas that unite the members of a given group (most often a social class) and oppose them to other groups" ${ }^{40}$ or as "the collective mental and psychological structure of a group at a given period which prescribed the range of possible ways within which individuals thought, felt, and acted." ${ }_{41}$ Studying the underlying collective consciousness, cosmology, or mentalité of a select group during a particular period involves historically reconstructing their shared psychological categories and modes of thought, their largely unconscious, internalized, and recurring patterns of understanding, valuation, and representation. Without their awareness, this mentality shaped and limited the ways in which members of the group or contemporaries of the period perceived, interpreted, and responded to their world. ${ }^{42}$

One point of access to a past mentality is the reading matter, especially the fiction, that was popular with the group. On one level popular fiction has often served as an important source of information; before the advent of electronic mass media, popular literature was one of the primary ways many readers came to learn about such subjects as foreign nations, sex, Jews, or their own history. Literary works have thus provided large numbers of people not only with much of the data but also with the images, symbols, and stereotypes they use to think about their world and themselves. Schenda's path-breaking Volk ohne Buch ${ }^{43}$ shows how certain recurrent themes, stereotypes, narrative strategies, and other conventions in late eighteenth- and early nineteenth-century popular reading matter helped shape the mentality of the German lower classes; Mosse, to cite another prominent example, has used popular literature to probe nineteenth- and early twentieth-cen- tury German popular conceptions of reality and their relation to nationalism and antisemitism; ${ }^{44}$ and most recently Paret has explored the way in which literary interpretations of historical subjects (Schiller's historical dramas, Fontane's works about Old Prussia, von Scheffel's novels about medieval German life) influenced the historical thinking of later generations and their sense of the German past. ${ }^{45}$

Popular literature can be read as more than simply one of the elements that help shape popular mentality. In recent literary theory the movement commonly known as reception theory, reception aesthetics, or readerresponse theory is concerned with the role of the reader in the literary process and with how readers in the past responded to the imaginative literature they read. This school maintains that it is the readers of a literary text who assign or construct its meaning by "concretizing" the text's multitude of "indeterminacies" or by "actualizing" the set of "schemata" of a work. ${ }^{46}$ Readers bring to a text their own "horizon," a certain context of preconceptions and implicit beliefs, a set of conventions and expectations; although they are seldom conscious of their horizon or mentality, they use it to interpret a literary text and assign to it a meaning. Readers from different social settings and historical periods bring varying cultural horizons or codes to any given text, and thus respond to it in different ways. By examining how various historical audiences received particular literary works, genres, techniques, themes, or conventions, the historian can begin to probe the mental world of the reader. ${ }^{47}$

The Rezeption- or Wirkungsgeschichte of literature can expand our understanding of the collective mentality of past audiences by exploring what a fictional work meant to readers within a specific historical setting. Since every author writes with some audience in mind, we must ask what understandings and assumptions were at work between the text's author and the text's readers, whether intended or actual. What common attitudes, expectations, and values did author and readers share - or 
fail to share? What themes, patterns of representation, or sets of conventions did an audience prefer in its literature? Thus, to take but one example of many, by examining both the public and the official responses to naturalistic dramas in imperial Germany, Brauneck demonstrated how works like Hauptmann's Die Weber were read (and misread) by different social groups like the educated middle class and the socialist working class; in doing so, he revealed much about the underlying fears, anxieties, and social and political concerns of these groups. ${ }^{48}$

Since the literary works or forms that were most popular (i.e., most widely read) were presumably the ones that coincided most closely to that group's mental horizon, bestselling popular fiction is the most revealing of the audience's mentality. The more popular a particular work was and the more enthusiastic its readers, the more likely it is that the cosmology expressed in the work matched that of the work's readership. In this way, one can say that the contents and strategies of popular reading matter reflect or document the mentalité of its readers and thus furnish a valuable source of information about the mental world of ordinary people in the past. ${ }^{49}$

Third, the purely imaginative, fictional element in certain literary works, usually ignored by historians, can also be valuable for studying the past. Aristotle, we should recall, noted that the historian describes what did happen, while the poet describes what might happen. A character in Don Quixote voiced a similar belief when he said that a poet describes things "not as they were, but as they ought to have been; but the historian has to write them down, not as they ought to have been, but as they were, without adding anything to the truth or taking anything from it." ${ }^{50}$ Although historical study is rightly concerned with what was rather than with what might or ought to have been, nevertheless there is a role in historical study for imagination, for speculation about what could or should have happened. Indeed some, like the noted historian Trevor-Roper, believe that only by considering what might have been can we really under- stand what actually was. "At any given moment of history," he argues,

there are real alternatives, and to discuss them as unreal because they were not realised . . . is to take the reality out of the situation. How can we explain what happened and why if we only look at what happened and never consider the alternatives, the total pattern of forces whose pressure created the event? . . . History is not merely what happened: it is what happened in the context of what might have happened. Therefore it must incorporate, as a necessary element, the alternatives, the might-havebeens. $^{51}$

It is precisely here, I would suggest, that imaginative literature can teach us historians something. When novelists or dramatists like Schiller or Döblin or Hauptmann or Hochhuth write about historical subjects like Wallenstein or the Silesian weavers' revolt or the German revolution of 1918 or the Vatican and World War II, they provide the historian with "alternative" views of what might have happened. (Likewise, utopian literature provides visions of alternate social or political outcomes.) Such alternative views can - and should - prompt historians to ask new questions about the past, to rethink why events happened as they did in these cases. While imaginative or fictionalized accounts of past people or events should certainly not be taken as historical knowledge, they often open the way for such knowledge. By providing a vision of alternate social or political outcomes, they can induce historians to reexamine an actual outcome as only one of many possible outcomes and to identify and analyze the factors and conditions that brought about this particular outcome. In other words, sometimes imaginative literature can prompt historians to see the past in fruitful new ways that can result in better historical explanations about what actually happened in the context of what might have happened. The controversy over Hochhuth's Der Stellvertreter, for example, has unleashed a whole new wave of historical research and historical insights into Vatican policy in World War II. 
Finally, in recent years historians have profited greatly from a close study of the internal, intrinsic aesthetic features of imaginative literature - that is, from the analysis of poetic form and style, linguistic structure, narrative emplotments, literary genre, and the like. By using some of the tools and methods of recent literary theory and criticism and applying these to historical writing, historians like Peter Gay, Hayden White, and Dominick LaCapra have inspired historians to rethink the very nature of our discipline and to see what we do in a whole new light. Gay, White, LaCapra, and others have pointed out the many similarities between literary and historical narrative; they have shown us that works of history, like those of literature, are verbal structures in the form of a narrative prose discourse with a deeper poetical, linguistic structural content. ${ }^{52}$ Like imaginative writers, all historians employ a certain style that consists of archetypical narrative emplotments, certain tropes of poetic language, and certain conceptual strategies by which they seek to explain or represent the historical data. These tropes and strategies of emplotment prefigure the historical data with which they deal. In short, recent applications of literary theory to historiography have pointed up the artistic components of history writing, the poetic and textual nature of any historical work. Whatever else it may be, history, we have come to realize once again, is really a branch of literature: the writing of history is a poetic act, and historical works are a literary form. Historical scholarship is as artistic as it is scientific; it contains creative and fictive elements, it relates both the real and the imagined. It is part memory, part imagination.

Such insights obviously have tremendous implications for all historians and for our entire discipline, implications that go far beyond the scope of this paper. Within the specific field of German intellectual history, however, these insights have been used to reinterpret the works of such noted German historians as Ranke, Burckhardt, and Marx. By recognizing the literary dimension of these authors' historical works and by analyzing their styles, lan- guage, and narrative strategies, we have come to reassess their general styles of thinking, their intentions, their values, and their scholarly achievements.

\section{IV}

I will conclude by citing the noted Roman historian Plutarch, who insisted that we should "take the stories least like poetry as our guide to the truth." ${ }^{53}$ Modern historians need not be nearly so cautious about relying on literature to learn about historical reality, but they must exercise care. Although there are formidable barriers to using literature to reconstruct past realities, they are not insurmountable. By paying as much, if not more attention to the methods of literary scholarship as to the contents of individual literary works, historians can rely on literature to increase their knowledge about the real past.

Picasso once characterized art as a lie that makes us realize the truth. Differentiating between the two has always been a challenging task.

\section{Notes}

'Aristotle, On Poetics, Chapter 9.

2 J. G. Herder, "Briefe zu Beförderung der Humanität. Achte Sammlung [1796]," Sämtliche Werke, ed. Bernhard Suphan (Berlin: Weidmann, 1877-1913), vol. 18: 137.

${ }^{3}$ Louis de Bonald, as quoted in Leo Lowenthal, Literature, Popular Culture, and Society (Palo Alto: Pacific Books, 1961) xi. (Lowenthal incorrectly identifies him as Charles de Bonald.)

${ }^{4}$ Peter Paret, Art as History. Episodes in the Culture and Politics of Nineteenth-Century Germany (Princeton: Princeton UP, 1988) 200, 5, 9.

${ }^{5}$ René Wellek and Austin Warren, Theory of Literature, 3rd ed. (San Diego: Harcourt Brace, 1977) 25, 110-11, $\rightarrow$ James Smith Allen, "History and the Novel: Mentalité in Modern Popular Fiction," History \& Theory 22 (1983): 237. Lionel Trilling, too, warns against an intellectualist misunderstanding of art and reminds us that one cannot organize works of art according to their ideas or their affinities with philosophical systems. (Trilling, "The Meaning of a Literary Idea," The Liberal Imagination. Essays on Literature and Society [New York: Viking, 1950] 281-303.)

${ }^{6}$ David Lodge, Language of Fiction. Essays on Criticism and Verbal Analysis of the English Novel (London: Routledge \& Kegan Paul, 1966) 46. 
${ }^{7}$ See Cleanth Brooks, "The Heresy of Paraphrase," The Well Wrought Urn. Studies in the Structure of Poetry (New York: Reynal \& Hitchcock, 1947) 192-214. Lodge 3-48 argues persuasively that the nonparaphrasability of poetry extends also to novels. The question of whether literary works can be adequately paraphrased or not is closely linked to the larger question of synonymity or semantic equivalence-i.e., whether different expressions can express the same meaning. As many linguists and philosophers have argued, the possibility of synonymy is questionable at best. See Leonard Linsky, "Synonymity," Encyclopedia of Philosophy, ed. Paul Edwards (New York: Macmillan, 1967), vol. 8: 54-57.

"Jonathan Cook, "Author" and "Discourse," and Gareth Griffiths, "Persona," A Dictionary of Modern Critical Terms, Revised and Enlarged Edition, ed. Roger Fowler (London: Routledge \& Kegan Paul, 1987) 15-17, 62-66, 176-77; Allen 236-37.

${ }^{9}$ Welleck and Warren 78.

10 Paret 201.

${ }^{11}$ Michel Foucault, "What is an author?" (1969) Language, Counter-Memory, Practice. Selected Essays and Interviews, ed. Donald F. Bouchard, trans. Donald F. Bouchard and Sherry Simon (Ithaca: Cornell UP, 1977) 113-38; Roland Barthes, "The Death of the Author" (1968), Image, Music, Text, ed. and trans. Stephen Heath (New York: Hill and Wang, 1977) 142-48. Also Cook 15-17, 62-66.

${ }^{12}$ The literature on the contemporary crisis and reorientation of intellectual history is enormous, but among the best are: Robert Darnton, "Intellectual and Cultural History," The Past Before Us. Contemporary Historical Writing in the United States, ed. Michael Kammen (Ithaca: Cornell UP, 1980) 327-54; Dominick LaCapra and Steven Kaplan, eds., Modern European Intellectual History. Reappraisals \& New Perspectives (Ithaca: Cornell UP, 1982); LaCapra, Rethinking Intellectual History: Texts, Contexts, Language (Ithaca: Cornell UP, 1983); and LaCapra, History \& Criticism (Ithaca: Cornell UP, 1985).

${ }^{13}$ See, for example, Roger Chartier, "Intellectual History or Sociocultural History? The French Trajectories," Martin Jay, "Should Intellectual History Take a Linguistic Turn? Reflections on the Habermas-Gadamer Debate," and Mark Poster, "The Future According to Foucault: The Archaeology of Knowledge and Intellectual History," in LaCapra and Kaplan, 13-46, 86-110, and 137-52, esp. 39-40, 95, 106, 143-44.

${ }^{14}$ Allan Rodway, "Criticism," in Fowler, Modern Critical Terms 46-48.

${ }^{15}$ See especially Jay 105 and LaCapra, "Rethinking Intellectual History and Reading Texts," in LaCapra and Kaplan, 47-85, as well as LaCapra's Rethinking Intellectual History.

${ }^{16}$ Friedrich Engels, and F. and Q. Leavis, as quoted in Morroe Berger, Real and Imagined Worlds. The Novel and Social Science (Cambridge, MA: Harvard UP, 1977) 1.

${ }^{17}$ For an excellent overview of the general unreliability of literary evidence in social history, $\rightarrow$ Peter Laslett, "The Wrong Way Through the Telescope: A Note on Literary Evidence in Sociology and Historical Sociology," British Journal of Sociology 27 (1976): 319-42. The following discussion draws heavily on Laslett's article.
${ }^{17}$ See W. K. Wimsatt, Jr. and Monroe C. Beardsley's famous essay "The Intentional Fallacy," in Wimsatt, The Verbal Icon. Studies in the Meaning of Poetry (Lexington: U of Kentucky P, 1954) 3-18, and their "Intention," Dictionary of World Literature: Criticism, Forms, Techniques, ed. Joseph T. Shipley (New York: Philosophical Library, 1943) $326-29$, in which they argue that "the design or intention of the author is neither available nor desirable as a standard for judging the success of a work of literary art." See also Allen 235-36.

${ }^{19}$ David Hackett Fischer, Historian's Fallacies. Toward a Logic of Historical Thought (New York: Harper \& Row, 1970) 62.

${ }^{20}$ Laslett 320-23, 328.

${ }^{21}$ Allen 236.

${ }^{22}$ Laslett 324.

${ }^{23}$ Laslett 324.

${ }^{24}$ Peter Mercer, "Realism," in Fowler, Modern Critical Terms 200.

${ }^{25}$ Fischer 109, 219.

${ }^{26}$ Laslett 323.

${ }^{27}$ Ernest K. Bramsted, Aristocracy and the MiddleClasses in Germany. Social Types in German Literature, 1830-1890 (1937; Chicago: U of Chicago P, 1964) 4.

${ }^{28}$ Laslett 331.

${ }^{29}$ Laslett 327.

${ }^{30}$ Aldous Huxley, Eyeless in Gaza (New York: Harper, 1936) 237.

${ }^{31}$ Laslett 324-25.

${ }^{32}$ Allen 239. See also Laslett 340.

${ }^{33}$ Dominick LaCapra (History \& Criticism 126) notes: "Literature becomes redundant when it tells us what can be gleaned from other documentary sources. In this sense, literature is paradoxically most superfluous when it seems to provide us with the most 'useful' and 'reputable' information, for it must simply replicate or confirm what can be found in more literal documents such as police reports. ... Literature is merely suggestive, for example, in giving us a 'feel' for life in the past, when its information cannot be checked against other sources. It must then be given secondclass status in historical scholarship, although what cannot be checked may bear upon some of the most significant and subtle processes in life."

${ }^{34}$ Laslett passim, but esp. 319, 328. This is why Laslett calls the use of literary evidence by social scientists, especially historical sociologists, "looking the wrong way through the telescope." "We cannot," he says, "get at the eyepiece Shakespeare used [when he looked out upon his social world]; we have, so to speak, to look through the orifice instead. What we perceive is not what Shakespeare saw, but Shakespeare's eye. Or rather that which Shakespeare chose to let us see of all that entered there" (319).

${ }^{35} \mathrm{~A}$ good beginning in this direction was made by the late Rolf Engelsing. See his Der literarische Arbeiter. Band I: Arbeit, Zeit und Werk im literarischen Beruf (Göttingen: Vandenhoeck \& Ruprecht, 1976).

${ }^{36} \mathrm{See}$, for example, my Entrepreneurs of Ideology. Neoconservative Publishers in Germany, 1890-1933 (Chapel Hill: U of North Carolina P, 1981); Sarah E. Thomas, "Hugo von Hofmannsthal and Anton Kippenberg of the Insel-Verlag: A Case Study of Author-Publisher Relations" (diss., Johns Hopkins U, 1982); and 
Lynda J. King, Best-Sellers By Design. Vicki Baum and the House of Ullstein (Detroit: Wayne State UP, 1988).

${ }^{37}$ I am currently engaged in a study of the institution of literary censorship in imperial Germany; for my preliminary findings, see my "Pornography, Society, and the Law in Imperial Germany," Central European History 14 (1981): 200-29; "The Censorship of Literary Naturalism, 1885-1895: Prussia and Saxony," Central European History 18 (1985): 326-43; "La police berlinoise et la Freie Volksbühne: Une étude de l'intégration socialiste," Revue d'Histoire du Théâtre 38 (1986): 7-19; and "Trials and Tribulations. Authors' Responses to Censorship in Imperial Germany, 1885-1914," German Studies Review, forthcoming. Wolfram Siemann is engaged in a similar comprehensive study of the impact of censorship in early nineteenth-century Germany. For a convenient overview of his work, see Siemann, "Ideenschmuggel. Probleme der Meinungskontrolle und das Los deutscher Zensoren im 19. Jahrhundert," Historische Zeitschrift 245 (1987): 71-106.

${ }^{3 *}$ Bodo Rollka, Die Belletristik in der Berliner Presse des 19. Jahrhunderts: Untersuchungen zur Sozialisationsfunktion unterhaltender Beiträge in der Nachrichtenpres$s e$, Einzelveröffentlichungen der Historischen Kommission zu Berlin (Berlin: Colloquium, 1985).

${ }^{39}$ Vernon L. Lidtke, The Alternative Culture. Socialist Labor in Imperial Germany (New York: Oxford UP, 1985) 158.

4) Lucien Goldmann, Le dieu caché. Étude sur la vision tragique dans les Pensées de Pascal et dans le théâtre de Racine (Paris, 1955), as quoted in Chartier 27.

${ }^{41}$ Ernst Breisach, Historiography. Ancient, Medieval, and Modern (Chicago: U of Chicago P, 1983) 372.

${ }^{42}$ For brief discussions of the concept of mentalité, see Chartier 22-32 $\rightarrow$ Patrick Hutton, "The History of Mentalities: The New Map of Cultural History," History \& Theory 20 (1981): 237-59.

${ }^{43}$ Rudolf Schenda, Volk ohne Buch. Studien zur Sozialgeschichte der populären Lesestoffe 1770-1910 (Frankfurt a. M.: Vittorio Klostermann, 1970).

${ }^{44}$ George Mosse, The Crisis of German Ideology. Intellectual Origins of the Third Reich (New York: Grosset \& Dunlap, 1964); The Nationalization of the Masses. Political Symbolism and Mass Movements in Germany from the Napoleonic Wars Through the Third Reich (New York: Fertig, 1975), and several of the essays in his Germans and Jews. The Right, the Left, and the Search for a "Third Force" in Pre-Nazi Germany (New York: Grosset \& Dunlap, 1970) and Masses and Man. Nationalist and Fascist Perceptions of Reality (New York:
Fertig, 1980).

${ }^{45}$ Paret passim.

${ }^{46}$ See Wolfgang Iser, The Act of Reading. A Theory of Aesthetic Response (Baltimore: Johns Hopkins UP, 1978) and The Implied Reader. Patterns of Communication in Prose Fiction from Bunyan to Beckett (Baltimore: Johns Hopkins UP, 1974); Hans Robert Jauss, Toward an Aesthetic of Reception, trans. Timothy Bahti (Minneapolis: U of Minnesota P, 1982); Hans-Georg Gadamer, Truth and Method, ed. and trans. Garrett Barden and John Cumming (New York: Seabury, 1975); Jayne P. Tompkins, ed., Reader-Response Criticism: From Formalism to Post-Structuralism (Baltimore: Johns Hopkins UP, 1980); Susan R. Suleiman and Inge Crosman, The Reader in the Text: Essays in Audience and Interpretation (Princeton: Princeton UP, 1980); and Robert C. Holub, Reception Theory: A Critical Introduction (London: Methuen, 1984).

${ }^{47}$ For a brief and cogent statement of how such a use of literature can provide new insights into social history, see Allen 245-52.

${ }^{48}$ Manfred Brauneck, Literatur und Öffentlichkeit im ausgehenden 19. Jahrhundert. Studien zur Rezeption des naturalistischen Theaters in Deutschland (Stuttgart: Metzler, 1974).

${ }^{49}$ Allen 248-49, 252; Chartier 36-42; LaCapra, History \& Criticism 129, 131.

5) Samson in Cervantes, Don Quixote, Part II, Chapter 3.

${ }^{51}$ Hugh Trevor-Roper, "History and Imagination. A Valedictory Lecture delivered before the University of $\mathrm{Ox}$ ford on 20 May 1980" (Oxford: Clarendon, 1980) 13, 15. He has made the same point in this recent "The Lost Moments of History," The New York Review of Books 35.16 (27 October 1988) 61: "Only if we see events in the setting of competing alternatives can our history claim to be objectively true."

${ }^{52}$ Peter Gay, Style in History (New York: Basic Books, 1974); Hayden White, Metahistory: The Historical Imag ination in Nineteenth-Century Europe (Baltimore: Johns Hopkins UP, 1973), and Tropics of Discourse. Essays in Cultural Criticism (Baltimore: Johns Hopkins UP, 1978) esp. 51-135; LaCapra, Rethinking Intellectual History and History \& Criticism. For another useful article on recent theories about the parallels between historical and literary writing, see Paul Michael Lützeler, "Geschichtsschreibung und Roman: Interdependenz und Differenz," Zeitgeschichte in Geschichten der Zeit. Deutschsprachige Romane im 20. Jahrhundert (Bonn: Bouvier, 1986) 2-25.

${ }^{53}$ Plutarch, The Lives of the Noble Greeks and Romans, Theseus. 